\title{
PERTUMBUHAN SETEK BEBERAPA VARIETAS Hoya coronaria DARI KAWASAN HUTAN KERANGAS AIR AINYIR, BANGKA
}

\author{
Ida Yulianti ${ }^{*}$, Yulian Fakhrurrozi ${ }^{1}$, Sri Rahayu ${ }^{2}$ \\ ${ }^{1}$ Jurusan Biologi, Universitas Bangka Belitung, Bangka, Indonesia \\ ${ }^{*}$ Corresponding author: idayulianti783@gmail.com \\ ${ }^{2}$ Lembaga Ilmu Pengetahuan Indonesia (LIPI), Bogor, Indonesia
}

\begin{abstract}
The research on vegetative propagation of several $H$. coronaria varieties from heath forest of Air Anyir Bangka, is the first step to cultivate as well as for conservation purpuses. This research purpose to study the growth of stem cutting from several $H$. coronaria varieties as well as to find the best cutting method. This research was done on Oktober 2015 until January 2016 at trial house on Gabek 2, Pangkalpinang. The experiment applied randomized factorial completely design of 2 factors with 15 level combinations. The first factor is 5 variety of $H$. coronaria and the second factor is 3 cutting methods with different leaves numbers. Three replications was applied with 3 cutting each of replications. The parameters were observed on the establishment of cuttings (life cutting presentation), root length, root total number, shoot total number, shoot length, stem diameter, leaves total number, leaf wide and internode total number. The result showed that most of all growth parameters except stem diameter were significantly influenced by the varieties differences. All growth parameters were also significantly influenced by the cutting methods as well as all treatment interaction. This result was assumed influence by cutting age an 7 weeks. The best fast growth varieties was variety 5 . The best cutting method was 4 leaves cutting. The best treatment interaction was variety 4 with 4 leaves cutting. The slowest growth varieties was variety 1 , and the slowest cutting was non leaves cutting. This result were assumed influencing by some factors such us the numbers of leave, nutrition, hormone, genetic and environment.
\end{abstract}

Keywords: Cutting, H. coronaria, heath forest, Bangka

\section{PENDAHULUAN}

Hoya coronaria merupakan salah satu tumbuhan epifit merambat yang termasuk ke dalam famili Apocynaceae: Asclepiadoideae. Tumbuhan ini termasuk tumbuhan sukulen dengan banyak lapisan lilin pada permukaan daun dan bunga (Rahayu, 2012). Bunga Hoya memiliki mahkota unik (korola) yang berbentuk seperti bintang dan juga memiliki mahkota tambahan (korona). H. coronaria memiliki keanekeragaman varietas yang dilihat dari warna bunga yang bervariasi. Rahayu (2010), menyebutkan bahwa Hoya di Indonesia telah banyak digemari sebagai tanaman indoor dan diperjualbelikan. Berdasarkan hasil survei pendahuluan selain dikembangkan sebagai tanaman hias, H. coronaria juga dimanfaatkan sebagai tanaman obat tradisional oleh masyarakat.

Habitat $H$. coronaria dapat ditemukan di hutan dengan tanah berpasir yang miskin hara. Salah satu hutan yang ditemukan adanya $H$. coronaria di Kepulauan Bangka Belitung ini yaitu di hutan kerangas Desa Air Anyir, Kecamatan Merawang Kabupaten Bangka. Hutan kerangas merupakan salah satu tipe hutan yang tumbuh di atas tanah podsol yang miskin akan unsur hara, banyak pasir kuarsa dan ber $\mathrm{pH}$ rendah. Kondisi hutan kerangas yang miskin hara mendukung keunikan komunitas tumbuhan yaitu banyak ditemukan tumbuhan epifit merambat yang berasosiasi dengan semut (Herzegovina, 2015).

Habitat $H$. coronaria di hutan kerangas sudah semakin terancam. Survei pendahuluan pada bulan September sampai Oktober 2015 menunjukkan bahwa beberapa titik lokasi di kawasan hutan kerangas Desa Air Anyir telah banyak mengalami kebakaran, sehingga jumlah $H$. coronaria sudah semakin sedikit. Perda Kabupaten Bangka No.1 Tahun 2013 juga menyebutkan bahwa kawasan hutan kerangas Air Anyir merupakan kawasan peruntukan industri. IUCN (The International Union for the Conservation of Nature) (2008 dalam Rahayu, 2010), juga mengkategorikan bahwa hutan kerangas merupakan salah satu hutan yang rawan, dimana jika hutan tersebut mengalami gangguan maka akan sulit untuk pulih kembali. Hal ini juga didukung oleh pernyataan Bruenig (1995 dalam Kissinger et al., 2013), yang menyebutkan bahwa hutan kerangas merupakan hutan yang mudah terdegradasi, dimana jika sekali mengalami degradasi maka akan berkembang menjadi savana terbuka (padang). Oleh karena itu, diperlukan upaya konservasi dan usaha budidaya terhadap tanaman Hoya.

Budidaya tanaman Hoya dapat dilakukan secara vegetatif dan generatif. Perbanyakan generatif adalah perbanyakan tanaman dari bahan yang berasal dari biji, sedangkan perbanyakan vegetatif adalah 
perbanyakan yang diperoleh dari organ vegetatif tanaman (Subiakto, 2009). Perbanyakan Hoya bisa menggunakan biji atau setek, namun jika ingin Hoya cepat berbunga sebaiknya menggunakan metode setek. Keuntungan perbanyakan dengan setek adalah mampu menghasilkan tanaman serupa dengan induknya dalam waktu yang relatif singkat dan sederhana (Pasetriyani, 2013). Berdasarkan survei pendahuluan di hutan kerangas Air Anyir ditemukan bahwa terdapat berbagai varietas $H$. coronaria. Perbedaan varietas dapat di lihat dari variasi warna bunganya. Menurut Sitompul dan Guritno (1995), menyebutkan bahwa perbedaan varietas akan menunjukkan perbedaan pertumbuhan tanaman. Namun untuk varietas $H$. coronaria ini belum diketahui apakah masing-masing dari varietas tersebut memiliki sifat pertumbuhan yang berbeda atau sama.

Perlakuan bahan setek terhadap beberapa varietas $H$. coronaria dengan mengikutsertakan 4 daun pada semua ruas, 2 daun pada semua ruas dan tanpa daun pada semua ruas juga perlu dilakukan. Hal ini mengingat karena kondisi dilapangan yang ekstrim akibat kebakaran, sehingga banyak dari varietas $H$. coronaria melakukan pertahanan diri dengan menggugurkan daun. Berdasarkan hal tersebut maka diamati bagaimana pertumbuhan vegetatif beberapa varietas $H$. coronaria akibat pengaruh dari perlakuan tersebut. Hal ini juga dapat melihat perlakuan setek mana yang paling baik untuk menanam. Penelitian mengenai pertumbuhan setek beberapa varietas $H$. coronaria dari kawasan hutan kerangas Anyir Anyir, Bangka ini belum pernah dilakukan.

\section{METODE PENELITIAN}

\section{Lokasi dan Waktu Penelitian}

Pengambilan sampel tumbuhan beberapa varietas H. coronaria di lakukan di hutan kerangas desa Air Anyir Kabupaten Bangka. Pengamatan mengenai pertumbuhan setek beberapa varietas $H$. coronaria dilakukan di tempat percobaan yang telah disiapkan di Gabek II Pangkalpinang. Kegiatan penelitian ini dilakukan pada Oktober 2015 - Januari 2016. Analisis mengenai media tanam dari tanah podsol dan moss dilakukan di Laboratorium Biologi dan MIPA, Fakultas Pertanian, Perikanan dan Biologi Universitas Bangka Belitung.

\section{Alat dan Bahan}

Alat yang digunakan dalam penelitian ini adalah alat tulis, baki, cawan aluminium, cawan porselin, furnace, gelas plastik transparan dengan diameter 9 $\mathrm{cm}$, gunting setek, jangka sorong, kamera Nikon DSLR 16,1 mp, karung, lux meter, oven, paranet, $\mathrm{pH}$ meter, penjepit cawan, penggaris, sarung tangan, termohigrometer, dan timbangan analitik. Bahan yang digunakan adalah alat tulis, kayu, kertas gravimetri, label, moss, paku, setek batang tumbuhan Hoya dengan 5 varietas, dan tanah podsol (moss dam tanah podsol diambil dari hutan kerangas Air Anyir habitat alami tumbuh $H$. coronaria).

\section{Cara Kerja}

Penelitian dilakukan dengan metode eksperimen menggunakan metode Rancangan Acak Lengkap (RAL) Faktorial yang melibatkan 2 faktor. Faktor pertama adalah varietas Hoya yang terdiri dari 5 varietas Hoya dan faktor kedua adalah setek batang jumlah daun berbeda (jumlah daun maksimum pada semua ruas, jumlah daun minimum dan tanpadaun). Kombinasi perlakuan yang diperoleh sebanyak 15 perlakuan yang diulang sebanyak 3 kali. Sampel yang digunakan yaitu 3 tanaman, sehingga total sampel adalah 135 tanaman.

Langkah-langkah penelitian yang dilakukan adalah: 1. Persiapan Tempat Percobaan

Persiapan yaitu terdiri dari pembuatan tempat percobaan. Tempat percobaan dibuat sebelum setek dipindahkan ke dalam gelas plastik transparan. Tempat setek dibuat dari rangka kayu dengan panjang $90 \mathrm{~cm}$, lebar $60 \mathrm{~cm}$ dan tinggi $130 \mathrm{~cm}$. Tempat setek ini diletakkan dibawah naungan yang tertutup oleh paranet dan pohon yang rindang. Hal ini bertujuan untuk menjaga kelembaban tanaman.

\section{Persiapan Media Tanam}

Bibit setek sebelum dipotong dan ditanam terlebih dahulu menyiapkan media tanam. Media tanam yang digunakan berupa tanah podsol dan moss. Moss disini digunakan hanya sebagai mulsa (penutup permukaan media tanam). Tanah podsol kemudian dimasukkan sebanyak $3 / 4$ dari gelas plastik transparan, kemudian moss ditambahkan secukupnya pada bagian atas tanah. Gelas plastik yang digunakan sebagai wadah diberi lubang pada bagian bawah secukupnya. Hal ini bertujuan untuk respirasi akar sehingga tidak menyebabkan pembusukan akar.

\section{Pengambilan Bahan Setek}

Bahan sampel setek yang diambil terdiri dari 5 varietas H.coronaria. Varietas 1 warna bunga peach, varietas 2 warna bunga putih dasi merah, varietas 3 warna bunga pink korona magenta, varietas 4 warna bunga putih polos, dan varietas 5 warna bunga merah gradasi (korola magenta, korona merah hati) (Tabel 1), 5 varietas ini dijadikan bahan penelitian karena masih memiliki karakteristik tanaman yang masih segar dan memiliki jumlah ruas yang banyak, sehingga jumlah sampel yang dibutuhkan dalam penelitian tercukupi. Setek yang dilakukan dalam penelitian ini yaitu setek batang. Kriteria bagian batang yang diambil yaitu pada bagian tengah. Hardjadinata (2010), menyebutkan bahwa batang yang terlalu tua memiliki zat tumbuh dan kandungan nutrisi yang sedikit, sedangkan batang yang terlalu muda memiliki kandungan air yang banyak. Batang yang dipotong untuk uji setek ini yaitu bagian pangkal 
bawah yang terdapat dua ruas daun keatas. Nalurita berukuran $3-5 \mathrm{~cm}$ atau 2 potongan mata tunas.

(2004),menyebutkan bahwa setek batang umumnya

Tabel 1. Perlakuan varietas yang digunakan dalam penelitian

\begin{tabular}{ll}
\hline Varietas & Warna bunga \\
\hline Varietas 1 & $\begin{array}{l}\text { Peach (korola peach, garis madu } \\
\text { magenta, korona magenta) }\end{array}$ \\
& $\begin{array}{l}\text { Putih dasi merah (korola putih, garis } \\
\text { madu merah, korona magenta) }\end{array}$ \\
\hline Varietas 2 & $\begin{array}{l}\text { Pink korona magenta (korola pink, garis } \\
\text { madu pink, korona magenta) }\end{array}$ \\
\hline Varietas 3 & $\begin{array}{l}\text { Putih polos (korola putih, tidak ada garis } \\
\text { madu, korona kuning) }\end{array}$ \\
\hline Varietas 4 & $\begin{array}{l}\text { Merah gradasi (korola magenta, } \\
\text { korona merah hati) }\end{array}$ \\
\hline Varietas 5 & \\
& \\
& \\
& \\
&
\end{tabular}

\section{Sumber: Dokumentasi Fakhrurrozi (2015)}

\section{Penanaman Setek}

Bibit setek yang telah dipotong dua ruas tiaptiap varietas ditanam kedalam gelas plastik transparan yang sebelumnya telah diisi media. Satu varietas terdapat 27 sampel uji, sehingga total bibit setek yang akan ditanam ada 135 buah. Bibit setek tersebut ditanam dengan 3 perlakuan, yaitu setek batang dengan 4 daun, setek batang dengan 2 daun dan setek batang dengan 0 daun (Tabel 2). Setek batang dengan 0 daun bertujuan untuk mempercepat pertumbuhan tunas atau dominansi apikal (Harjanto \& Nisa, 2007). Hal tersebut juga dikarenakan kondisi tumbuhan di lapangan, dimana banyak daun yang kering dan mati akibat musim kemarau. Setek batang dengan daun dapat mempercepat pertumbuhan akar (Sandra 2008). Setek yang telah dipotong langsung ditanam kedalam media. Setek ditanam umumnya dengan kedalaman 1/3-1/2 dari bagian setek batang. Hal ini untuk memudahkan setek yang ditanam agar tidak terlalu tinggi dan tidak terlalu rendah.

Tabel 2. Perlakuan setek yang digunakan dalam penelitian

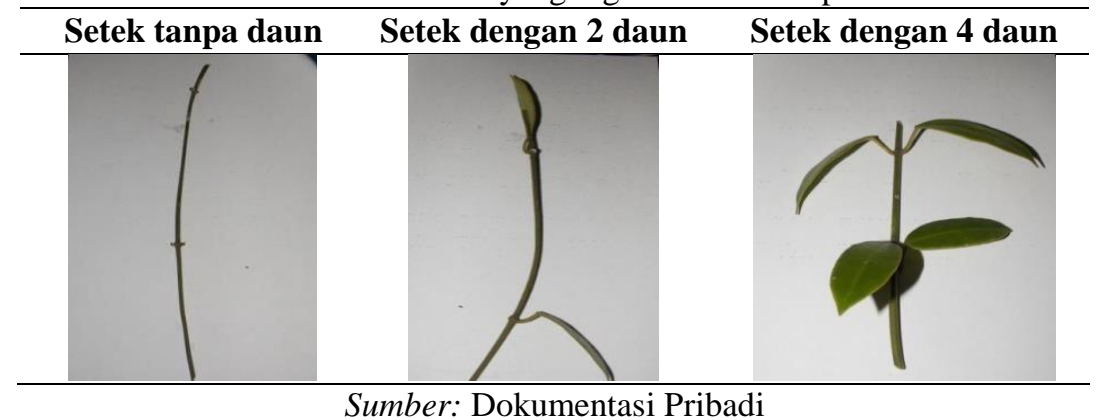




\section{Pemeliharaan Setek}

Pemeliharaan bibit setek ini yaitu dengan melakukan penyiraman dan pembersihan gulma. Penyiraman dilakukan 2 kali sehari pada pagi dan sore hari. Penyiraman ini menggunakan air bersih yang disiram secukupnya, namun pada saat hujan penyiraman bisa dikurangi atau tidak dilakukan sama sekali. Hal ini untuk menghindari terjadinya pembusukan akar dan batang (Hardjadinata, 2010). Pengendalian gulma dilakukan secara manual yaitu dengan mencabuti gulma yang tumbuh di sekitar sampel uji. Hal ini bertujuan agar tidak mengganggu pertumbuhan tumbuhan uji dan mencegah terjadinya penyakit.

\section{Pengamatan dan Pengukuran}

\section{Pengamatan Parameter Pertumbuhan}

Parameter pengamatan dan pengukuran yang diamati dalam pertumbuhan setek ini yaitu:

\section{a. Persentase setek hidup}

Persentase setek hidup dilakukan dengan menghitung jumlah tumbuhan yang hidup pada masing-masing perlakuan diminggu ke-7 dibagi dengan total jumlah tumbuhan yang ditanam pada masing-masing perlakuan.

\section{b. Pertumbuhan Tunas}

Pengamatan dilakukan dengan mengamati pertumbuhan tunas (minggu), dan persentase tumbuh tunas. Pengamatan pertumbuhan tunas berhenti setelah tunas berumur 7 minggu. Persentase tumbuh tunas dilakukan dengan cara menghitung persentase tunas setiap perlakuan bahan setek yang tumbuh pada minggu ke-1 (Kaisar, 2014). Pengamatan dan pengukuran terhadap pertumbuhan tunas ini dilakukan 1 minggu satu kali sampai akhir pengamatan.

\section{c. Tinggi Batang ( $\mathrm{cm})$}

Tinggi batang utama yaitu diukur dari bagian pangkal yang berada dibagian permukaan media sampai bagian ujung atau pucuk. Pengukuran ini dilakukan diawal dan diakhir penelitian. Hal ini karena pertumbuhan tinggi batang utama setek relatif kecil. Tinggi batang baru (dari tunas) juga diukur setelah akhir pengamatan.

\section{d. Pertumbuhan Daun}

Pertumbuhan daun diukur dengan menghitung berapa jumlah daun baru yang telah tumbuh dan luas daun. Luas daun awal pada perlakuan setek dengan 4 daun dan 2 daun diukur terlebih dahulu diawal penanaman. Daun yang akan diukur sebelumnya diberi label terdahulu. Hal ini untuk mencegah kekeliruan tertukarnya daun saat pengukuran di akhir penelitian. Perhitungan luas daun dilakukan pada minggu pertama dan akhir penelitian. Luas daun diukur menggunakan kertas gravimetri. Daun yang akan dihitung luasnya digambar diatas kertas, lalu pola kertas digunting sesuai dengan ukuran daun tersebut. Pola daun kertas yang telah digunting kemudian ditimbang menggunakan timbangan analitik. Perhitungan luas daun yaitu berat pola kertas dibagi dengan berat kertas ukuran 100 cm2, kemudian dikali dengan luas kertas 100 cm2 . Sandra (2008) menyebutkan bahwa luas daun dapat dihitung dengan menggunakan metode gravimetri. Metode ini sederhana, mudah dilakukan dan keakuratannya juga tinggi.

\section{e. Diameter Batang}

Diameter batang diukur menggunakan alat jangka sorong. Diameter yang diukur yaitu bagian pangkal dan ujung batang. Diameter batang baru juga diukur setelah ukuran batang (tunas) mencapai panjang $6 \mathrm{~cm}$ dari titik tunas tumbuh (Bayu 2013). Pengukuran terhadap diameter batang dilakukan diawal dan diakhir pengamatan. Hal ini dilakukan karena pertambahan tehadap diameter batang relatif bernilai kecil. Pengukuran dilakukan pada titik yang sama sampai akhir pengamatan.

\section{f. Jumlah Ruas Batang}

Jumlah ruas ini diukur dengan melihat berapa jumlah daun yang tumbuh. Daun yang tumbuh pada setiap batang menunjukkan munculnya ruas batang. Jumlah daun yang tumbuh pada batang 1 atau 2 maka jumlah ruas batang yaitu 1. Jumlah daun pada batang 3 atau 4 maka ruas batang yaitu 2. Hal ini karena umumnya $H$. coronaria memiliki daun yang berhadapan.

\section{g. Pertumbuhan Akar}

Pengamatan terhadap akar ini yang dilihat yaitu tumbuh tidaknya akar, jumlah akar dan panjang akar. Pengamatan terhadap akar ini dilakukan di akhir penelitian dengan membongkar akar dalam media. Akar dibersihkan dengan air bersih dari media yang menempel. Hal ini untuk memudahkan dalam pengamatan.

\section{Pengukuran Karakteristik Media}

Media yang diukur yaitu moss dan tanah podsol. Sifat kimia media yang diukur yaitu meliputi $\mathrm{pH}$ tanah, kadar air dan kandungan organik serta anorganik. Pengukuran ini dilakukan sebanyak 3 kali ulangan.

a. $p H$

Pengukuran $\mathrm{pH}$ menggunakan $\mathrm{pH}$ meter (Diaguna, 2014). Metode yang dilakukan yaitu pertama tanah dan moss di ambil sebanyak 10 gram, kemudian dimasukkan kedalam botol dan ditambahkan $10 \mathrm{ml}$ air destilasi, dikocok selama 30 menit dengan menggunakan shaker, dan setelah itu didiamkan. Larutan penyangga 
(buffer) diukur terlebih dahulu sebagai kontrol ( $\mathrm{pH} 4$ dan $\mathrm{pH}$ 7) sebelum mengukur $\mathrm{pH}$ meter. $\mathrm{pH}$ meter setelah di kalibrasi dengan larutan penyangga langsung dapat digunakan. Hal ini untuk mencegah terjadinya eror dan hasil yang diperoleh lebih akurat. Botol sampel yang telah didiamkan kemudian diletakkan pada bagian bawah ujung pena $\mathrm{pH}$ meter. Ujung pena $\mathrm{pH}$ meter dicelupkan kedalam air botol sampel. Tekan SC dan Run pada alat tersebut dan tunggu sampai ada bunyi pada $\mathrm{pH}$ meter. Setelah berbunyi, hasil $\mathrm{pH}$ yang keluar dicatat.

\section{b. Kadar Air}

Kadar air dianalisis menggunakan oven (Tan, 2005; Abdurachman et al tanpa tahun dalam Kurnia et al., 2006). Metode ini dilakukan dengan cara mengambil cuplikan media (tanah dan moss) sebanyak 10 gram. Media tersebut kemudian dimasukkan kedalam oven dengan suhu $105^{\circ} \mathrm{C}$ selama 24 jam. Media yang telah dioven dimasukkan kedalam desikator untuk di dinginkan. Pengukuran persentase kadar air tanah yaitu dari berat tanah basah dikurangi dengan berat tanah kering oven kemudian dibagi dengan berat tanah kering oven. Kadar air moss juga diukur dengan metode yang sama dengan kadar air tanah.

\section{c. Kandungan organik dan anorganik}

Kandungan organik dan anorganik media ditentukan dengan cara mengambil cuplikan media sebanyak 5 gram. Cuplikan media tersebut dimasukkan kedalam porselen kering dan diabukan dalam furnace pada suhu $450 \mathrm{oC}$ selama 1-4 jam hingga media menjadi putih keabuan (Putra, 2013 dalam Herzegovina, 2015). Media yang telah diabukan dimasukkan kedalam desikator untuk didinginkan. Kandungan organik media dihitung sebagai persentase dari berat kering media dikurang berat abu media dibagi dengan berat kering media. Kandungan anorganik media dihitung sebagai persentase dari berat abu media dibagi dengan berat kering media.

\section{Pengukuran Faktor Lingkungan}

Faktor lingkungan yang diukur yaitu suhu, kelembaban udara dan intensitas cahaya. Parameter ini diukur dengan termohigrometer dan lux meter. Pengukuran terhadap faktor lingkungan ini diukur setiap hari atau setiap kali pengamatan.

\section{Analisis Data}

Data hasil pengamatan yang telah diperoleh dianalisis menggunakan Analisis Ragam (ANOVA) dan uji lanjut BNT dengan tingkat kepercayaan 95\%. Analisis ini menggunakan software SPSS statistics 21 dan Microsoft excel untuk mempermudah dalam perhitungan.

\section{HASIL DAN PEMBAHASAN}

\section{Hasil}

Media merupakan faktor penting dalam bercocok tanam. Media membantu tanaman dalam memperoleh unsur hara, mendukung tumbuhnya akar dan menopang tegaknya batang. Media tanam yang digunakan yaitu tanah podsol dan moss sebagai mulsa. Kandungan kimia yang diukur yaitu kadar air, kadar organik, kadar anorganik dan $\mathrm{pH}$. Hasil analisis menunjukkan bahwa media memiliki pengaruh yang sangat nyata terhadap sifat kimia tanah (Tabel 3). Hal ini menunjukkan bahwa podsol dan moss memiliki kandungan hara yang berbeda-beda sehingga mempengaruhi pertumbuhan tanaman.

Tabel 3. Hasil analisis ragam perlakuan media terhadap sifat kimia tanah

\begin{tabular}{lcr}
\multicolumn{1}{c}{ Peubah } & F. hitung Media & \% KK \\
\hline Kadar air & $48.40 * *$ & $31.68 \%$ \\
Kadar organik & $661.88 * *$ & $5.97 \%$ \\
Kadar anorganik & $661.82 * *$ & $0.20 \%$ \\
pH & $578.42 * *$ & $1.14 \%$
\end{tabular}

Ket. *: berpengaruh nyata; **: berpengaruh sangat nyata; tn: tidak berpengaruh nyata; \%KK: Koefisien Keragaman

Tabel 4. Hasil uji lanjut BNT perlakuan media terhadap sifat kimia tanah

\begin{tabular}{lcccc}
\hline \multicolumn{1}{c}{ Media } & Kadar Air (\%) & Kadar Organik (\%) & Kadar Anorganik (\%) & $\mathbf{p H}$ \\
\hline Podsol & $1.06 \mathrm{~b}$ & $1.18 \mathrm{~b}$ & $98.83 \mathrm{a}$ & $4.02 \mathrm{~b}$ \\
Moss & $20.1 \mathrm{a}$ & $5.12 \mathrm{a}$ & $94.88 \mathrm{~b}$ & $5.04 \mathrm{a}$ \\
\hline
\end{tabular}

Ket: Nilai rataan pada kolom yang sama yang diikuti huruf yang berbeda menunjukkan perbedaan yang nyata menurut uji BNT dengan tingkat kepercayaan $95 \%$ 
Perlakuan yang menunjukkan adanya pengaruh yang sangat nyata terhadap peubah yang diamati dilakukan analisis lanjutan dengan uji lanjut BNT (Beda nyata terkecil). Hasil uji lanjut menunjukkan bahwa angka yang diikuti dengan huruf yang tidak sama pada setiap perlakuan menunjukkan bahwa adanya pengaruh yang nyata pada taraf $\alpha 0.05$ (Tabel 4).

Faktor lingkungan sangat mempengaruhi pertumbuhan tanaman.Suhu yang cocok untuk pertumbuhan tanaman umumnya tidak terlalu tinggi dan tidak terlalu rendah. Suhu yang tinggi dapat menyebabkan tanaman mengalami stress air, sedangkan jika suhu terlalu rendah dapat menyebabkan pembusukan tanaman misalnya busuknya pangkal batang. Suhu yang tinggi memiliki intensitas cahaya tinggi dan kelembaban rendah. Faktor lingkungan yang diukur yaitu suhu udara, kelembaban udara dan intensitas cahaya. Faktor ini diukur pada pagi dan sore hari (Tabel 5).

Tabel 5. Rata-rata kondisi faktor lingkungan di sekitar tanaman setek pada pagi dan sore hari selama 7 minggu

\begin{tabular}{cccc}
\hline Waktu & Suhu $\left({ }^{\mathbf{0}} \mathbf{C}\right)$ & Kelembaban $(\%)$ & Intensitas Cahaya (lux) \\
\hline Pagi & 28,52 & 82,67 & 3672,5 \\
Sore & 28,53 & 82,42 & 2888,6 \\
\hline
\end{tabular}

Berdasarkan penelitian yang dilakukan diperoleh bahwa dua faktor perlakuan menunjukkan adanya pengaruh yang nyata terhadap semua parameter pertumbuhan. Perlakuan yang digunakan yaitu perlakuan varietas dan setek. Parameter pertumbuhan yang diamati diantaranya yaitu persentase setek hidup, jumlah akar, panjang akar, jumlah tunas, tinggi tunas, diameter batang, jumlah ruas batang, jumlah daun, dan luas daun. Hasil di dapatkan bahwa perlakuan varietas menunjukkan pengaruh yang nyata terhadap 9 parameter pertumbuhan kecuali diameter batang. Perlakuan setek menunjukkan pengaruh yang nyata terhadap semua parameter pertumbuhan. Interaksi antara perlakuan varietas dan setek juga menunjukkan adanya pengaruh yang nyata terhadap semua parameter pertumbuhan (Tabel 6). Interaksi perlakuan merupakan adanya hubungan saling memperngaruhi antara dua perlakuan varietas dan setek.

Tabel 6. Hasil analisis ragam perlakuan varietas dan setek terhadap parameter pertumbuhan

\begin{tabular}{lllll}
\hline Peubah & \multicolumn{2}{c}{ F.hitung } & \multicolumn{2}{c}{ \% KK } \\
\cline { 2 - 4 } & Varietas & setek & Interaksi & \\
\hline \% setek hidup & $6.61 * *$ & $23.73 * *$ & $4.07 * *$ & $29 \%$ \\
Jumlah akar & $18.16 * *$ & $99.92 * *$ & $7.42 * *$ & $31 \%$ \\
Panjang akar & $4.75 * *$ & $62.52 * *$ & $2.33 *$ & $36 \%$ \\
Jumlah tunas & $4.11 * *$ & $10.35 * *$ & $2.97 *$ & $44 \%$ \\
Tinggi tunas & $14.04 * *$ & $17.21 * *$ & $8.40 * *$ & $34 \%$ \\
Diameter batang & $1.01 \mathrm{tn}$ & $7.49 * *$ & $5.32 * *$ & $47 \%$ \\
jumlah ruas batang & $3.84 *$ & $3.41 *$ & $3.82 * *$ & $73 \%$ \\
Jumlah daun & $4.35 * *$ & $3.48 *$ & $4.15 * *$ & $76 \%$ \\
Luas daun & $3.59 *$ & $5.45 * *$ & $2.49 *$ & $77 \%$ \\
\hline
\end{tabular}

Ket. *: berpengaruh nyata; **: berpengaruh sangat nyata; tn: tidak berpengaruh nyata; \%KK: Koefisien Keragaman

Perlakuan yang menunjukkan adanya pengaruh yang sangat nyata terhadap parameter pertumbuhan dilakukan analisis lanjutan dengan uji lanjut BNT (Beda nyata terkecil). Uji ini dilakukan untuk melihat perbandingan pengaruh perlakuan antar varietas dan setek serta untuk melihat perlakuan terbaik dari setiap perlakuan. Hasil uji lanjut didapatkan bahwa angka yang diikuti dengan huruf yang tidak sama pada setiap perlakuan menunjukkan bahwa adanya pengaruh yang nyata pada taraf $\alpha$ 0.05 (Tabel 7).

Tabel 7. Hasil analisis uji BNT perlakuan varietas, setek dan interaksi antara varietas dan setek terhadap semua

\begin{tabular}{lllllllllll}
\multicolumn{8}{c}{ parameter pertumbuhan tanaman } \\
\hline P & \%SH & JA & PA & JT & TT & DB & JRB & JD & LD \\
\cline { 2 - 11 } & \multicolumn{10}{c}{ Varietas } \\
\hline V1 & $51.85 \mathrm{~b}$ & $15.59 \mathrm{a}$ & $4.02 \mathrm{ab}$ & $2.56 \mathrm{ab}$ & $1.54 \mathrm{bc}$ & 0.09 & $0.33 \mathrm{a}$ & $0.44 \mathrm{~b}$ & $0.84 \mathrm{a}$ \\
$\mathrm{V} 2$ & $62.96 \mathrm{~b}$ & $4.37 \mathrm{c}$ & $4.06 \mathrm{ab}$ & $2.33 \mathrm{ab}$ & $1.04 \mathrm{c}$ & 0.08 & $1.33 \mathrm{a}$ & $2.22 \mathrm{ab}$ & $1.35 \mathrm{a}$ \\
\hline
\end{tabular}




\begin{tabular}{|c|c|c|c|c|c|c|c|c|c|}
\hline$\overline{\mathrm{V} 3}$ & $70.37 \mathrm{ab}$ & $12.44 \mathrm{a}$ & $4.18 \mathrm{ab}$ & $2.44 \mathrm{ab}$ & $1.83 \mathrm{bc}$ & 0.09 & $1.33 \mathrm{a}$ & $2.56 \mathrm{ab}$ & $2.86 \mathrm{a}$ \\
\hline V4 & $77.78 \mathrm{ab}$ & $6.74 \mathrm{bc}$ & $2.41 \mathrm{~b}$ & $2.11 \mathrm{~b}$ & $3.33 \mathrm{a}$ & 0.07 & $1.89 \mathrm{a}$ & $3.44 \mathrm{ab}$ & $1.88 \mathrm{a}$ \\
\hline V5 & $100.00 \mathrm{a}$ & $11.93 \mathrm{ab}$ & $5.38 \mathrm{a}$ & $4.11 \mathrm{a}$ & $2.50 \mathrm{ab}$ & 0.11 & $2.00 \mathrm{a}$ & $3.78 \mathrm{a}$ & $3.17 \mathrm{a}$ \\
\hline \multicolumn{10}{|c|}{ Setek } \\
\hline$\overline{\text { ST0 }}$ & $42.22 \mathrm{~b}$ & $1.91 \mathrm{c}$ & $1.08 \mathrm{c}$ & $1.60 \mathrm{~b}$ & $1.24 \mathrm{~b}$ & $0.06 \mathrm{~b}$ & $1.07 \mathrm{a}$ & $1.93 \mathrm{a}$ & $0.99 \mathrm{a}$ \\
\hline ST2 & $84.45 \mathrm{a}$ & $10.27 \mathrm{~b}$ & $3.94 \mathrm{~b}$ & $3.07 \mathrm{ab}$ & $2.16 \mathrm{a}$ & $0.09 \mathrm{ab}$ & $1.13 \mathrm{a}$ & $2.00 \mathrm{a}$ & $2.25 \mathrm{a}$ \\
\hline ST4 & $91.11 \mathrm{a}$ & $18.47 \mathrm{a}$ & $7.01 \mathrm{a}$ & $3.47 \mathrm{a}$ & $2.75 \mathrm{a}$ & $0.12 \mathrm{a}$ & $1.93 \mathrm{a}$ & $3.53 \mathrm{a}$ & $2.82 \mathrm{a}$ \\
\hline \multicolumn{10}{|c|}{ Interaksi antara varietas dan setek } \\
\hline$\overline{\mathrm{V} 1 \mathrm{ST} 0}$ & $0.00 \mathrm{~d}$ & $0.00 \mathrm{~h}$ & $0.00 \mathrm{~h}$ & $0.00 \mathrm{~g}$ & $0.00 \mathrm{~g}$ & $0.00 \mathrm{i}$ & $0.00 \mathrm{~h}$ & $0.00 \mathrm{f}$ & $0.00 \mathrm{~g}$ \\
\hline V1ST2 & $88.89 a$ & $20.33 \mathrm{~b}$ & $5.12 \mathrm{~cd}$ & $4.00 \mathrm{ab}$ & $1.73 \mathrm{de}$ & $0.14 \mathrm{a}$ & $0.00 \mathrm{~h}$ & $0.00 \mathrm{f}$ & $0.00 \mathrm{~g}$ \\
\hline V1ST4 & $66.67 \mathrm{~b}$ & $26.44 \mathrm{a}$ & $6.93 \mathrm{ab}$ & $3.67 \mathrm{~b}$ & $2.90 \mathrm{c}$ & $0.14 \mathrm{ab}$ & $1 \mathrm{efg}$ & $1.33 \mathrm{def}$ & $2.53 \mathrm{cde}$ \\
\hline V2ST0 & $33.33 \mathrm{c}$ & $1.67 \mathrm{gh}$ & $1.39 \mathrm{~g}$ & $1.67 \mathrm{ef}$ & $0.37 \mathrm{~g}$ & 0.10 cde & $2.00 \mathrm{~cd}$ & $3.33 \mathrm{c}$ & $0.73 \mathrm{fg}$ \\
\hline V2ST2 & $66.67 \mathrm{~b}$ & $3.11 \mathrm{fg}$ & $3.38 \mathrm{f}$ & $1.67 \mathrm{ef}$ & $1.47 \mathrm{def}$ & $0.04 \mathrm{~g}$ & $0.67 \mathrm{fgh}$ & $1.00 \mathrm{ef}$ & 1.39 ef \\
\hline V2ST4 & $88.89 \mathrm{a}$ & $8.34 \mathrm{e}$ & $7.42 \mathrm{a}$ & $3.67 \mathrm{~b}$ & $1.30 \mathrm{ef}$ & $0.09 \mathrm{de}$ & $1.33 \mathrm{def}$ & 2.33 cde & $1.94 \mathrm{de}$ \\
\hline V3ST0 & $11.11 \mathrm{~d}$ & $0.00 \mathrm{~h}$ & $0.00 \mathrm{~h}$ & $0.33 \mathrm{~g}$ & $0.43 \mathrm{~g}$ & $0.01 \mathrm{hi}$ & $0.00 \mathrm{~h}$ & $0.00 \mathrm{f}$ & $0.00 \mathrm{~g}$ \\
\hline V3ST2 & $100.00 \mathrm{a}$ & $12.67 \mathrm{~d}$ & $5.59 \mathrm{~cd}$ & $3.67 \mathrm{~b}$ & $1.97 \mathrm{~d}$ & $0.13 \mathrm{abc}$ & $1.33 \mathrm{def}$ & $2.67 \mathrm{~cd}$ & $5.27 \mathrm{a}$ \\
\hline V3ST4 & $100.00 \mathrm{a}$ & $24.67 \mathrm{a}$ & $6.94 \mathrm{ab}$ & $3.33 \mathrm{bc}$ & $3.10 \mathrm{bc}$ & $0.15 \mathrm{a}$ & $2.67 \mathrm{bc}$ & $5.00 \mathrm{~b}$ & $3.30 \mathrm{bc}$ \\
\hline V4ST0 & $66.67 \mathrm{~b}$ & $0.11 \mathrm{~h}$ & $0.08 \mathrm{~h}$ & $1.33 \mathrm{f}$ & $1.97 \mathrm{~d}$ & $0.04 \mathrm{gh}$ & $0.33 \mathrm{gh}$ & $0.33 \mathrm{f}$ & $0.26 \mathrm{fg}$ \\
\hline V4ST2 & $66.67 \mathrm{~b}$ & $4.33 \mathrm{f}$ & $0.99 \mathrm{gh}$ & $2.33 \mathrm{de}$ & $2.77 \mathrm{c}$ & $0.05 \mathrm{fg}$ & $1.67 \mathrm{de}$ & $3.00 \mathrm{c}$ & 2.49 cde \\
\hline V4ST4 & $100.00 \mathrm{a}$ & $15.78 \mathrm{c}$ & $6.18 \mathrm{bc}$ & $2.67 \mathrm{~cd}$ & $5.27 \mathrm{a}$ & $0.13 a b c$ & $3.67 \mathrm{a}$ & $7.00 \mathrm{a}$ & $2.89 \mathrm{bcd}$ \\
\hline V5ST0 & $100.00 \mathrm{a}$ & $7.78 \mathrm{e}$ & 3.94 ef & $4.67 \mathrm{a}$ & $3.43 \mathrm{~b}$ & $0.13 a b c$ & $3.00 \mathrm{ab}$ & $6.00 \mathrm{ab}$ & $3.94 \mathrm{~b}$ \\
\hline V5ST2 & $100.00 \mathrm{a}$ & $10.89 \mathrm{~d}$ & $4.62 \mathrm{de}$ & $3.67 \mathrm{~b}$ & $2.87 \mathrm{c}$ & $0.11 \mathrm{bcd}$ & $2.00 \mathrm{~cd}$ & $3.33 \mathrm{c}$ & $2.12 \mathrm{de}$ \\
\hline V5ST4 & $100.00 \mathrm{a}$ & $17.11 \mathrm{c}$ & $7.57 \mathrm{a}$ & $4.00 \mathrm{ab}$ & $1.20 \mathrm{f}$ & 0.07 ef & $1.00 \mathrm{efg}$ & $2.00 \mathrm{cde}$ & $3.45 \mathrm{bc}$ \\
\hline
\end{tabular}

Ket. Nilai rataan pada kolom yang sama yang diikuti huruf yang berbeda menunjukkan perbedaan yang nyata menurut uji BNT dengan tingkat kepercayaan 95\%, P: Perlakuan, \%SH: persentase setek hidup, PA: panjang akar, JA: jumlah akar, JT: jumlah tunas, TT: tinggi tunas, DB: diameter batang, JRB: jumlah ruas batang, JD: jumlah daun, LD: luas daun, ST0: setek tanpa daun, ST2: setek dengan 2 daun, ST4: setek dengan 4 daun, V1: varietas 1, V2: varietas 2, V3: varietas 3, V4: varietas 4, V5: varietas 5

\section{Pembahasan}

Hasil penelitian menunjukkan bahwa perlakuan varietas berpengaruh nyata terhadap beberapa parameter pertumbuhan kecuali diameter batang tunas diduga karena setiap varietas memiliki fisiologis tanaman yang berbeda-beda. Fisiologis tanaman yang berbeda pada setiap varietas salah satunya dapat dilihat dari warna bunga. Warna bunga yang digunakan dalam penelitian dan diperlakukan sebagai perlakuan memiliki warna bunga dengan korola dan korona yang berbeda.

Perbedaan karakter yang dapat terlihat pada setiap varietas ini diduga memiliki pengaruh yang berbeda pula terhadap pertumbuhan setek. Hal ini didukung oleh pernyataan Kartika et al., (2002 dalam Bayu, 2013), yang menyebutkan bahwa keadaan fisiolgis tanaman yang berbeda dalam suatu varietas akan menyebabkan pertumbuhan yang berbeda pula. Sitompul dan Guritno (1995), juga menyebutkan bahwa perbedaan varietas merupakan salah satu faktor penyebab keragaman penampilan tanaman. Hal ini karena faktor genetik yang berbeda dapat diekspresikan pada berbagai sifat tanaman yang mencakup bentuk dan fungsi tanaman yang menghasilkan keragaman pertumbuhan tanaman.
Perlakuan setek berpengaruh nyata terhadap beberapa parameter pertumbuhan kecuali jumlah daun tunas dan jumlah ruas batang tunas. Hal ini diduga karena adanya pengaruh kandungan nutrisi, hormon dan lingkungan. Hal ini didukung oleh pernyataan Baraer (1972), yang menyebutkan bahwa pertumbuhan vegetatif setek tanaman dipengaruhi oleh hormon dan nutrisi tanaman.

Berdasarkan rata-rata hasil dari perlakuan varietas dan setek terhadap 9 parameter pertumbuhan menunjukkan bahwa perlakuan varietas yang paling baik yaitu varietas 5 (Tabel 7). Hal ini diduga varietas 5 memiliki kemampuan fisiologis yang baik untuk beradaptasi terhadap pengaruh disekitarnya. Varietas 5 tumbuh lebih cepat dibandingkan dengan varietas lainnya. Hal ini dapat dilihat dari nilai panjang akar, diameter batang, jumlah ruas batang, jumlah daun dan luas daun yang paling tinggi yaitu pada varietas 5. Perlakuan setek yang paling baik yaitu setek berdaun 4 (Tabel 7). Hal ini diduga jumlah daun yang banyak akan memiliki kandungan makanan yang banyak pula. Selain itu, daun menghasilkan hormon auksin dan sitokinin, dimana hormon ini mendukung mempercepat pertumbuhan tanaman. Hal ini didukung oleh pernyataan Dewi (2008), yang 
menyatakan bahwa auksin dan sitokinin dalam tumbuhan akan mempengaruhi pertumbuhan tanaman. Auksin berfungsi salah satunya untuk memperpanjang batang, percabangan akar dan dominansi apikal. Sitokinin berfungsi untuk pemanjangan akar, pembelahan sel dan menunda penuaan.

Interaksi perlakuan terbaik dalam penelitian ini yaitu pada varietas 4 dengan setek berdaun 4 (Tabel 7). Hasil yang didapatkan bahwa varietas ini memiliki pertumbuhan yang cepat, hal ini dapat dilihat dari tinggi tunas, jumlah ruas batang tunas dan jumlah daun tunas yang lebih tinggi daripada interaksi perlakuan lainnya. Cepatnya pertumbuhan tanaman setek ini diduga interaksi perlakuan ini cocok terhadap kondisi lingkungan sekitarnya. Hal ini didukung oleh pernyataan Simatupang (1997 dalam Mardiati 2007), yang menyebutkan bahwa tingginya produksi suatu varietas disebabkan bahwa varietas tersebut mampu beradaptasi dengan lingkungannya.

Berdasarkan rata-rata hasil dari perlakuan varietas terhadap 9 parameter pertumbuhan menunjukkan bahwa varietas terendah yaitu varietas 1 (Tabel 7). Hal ini juga dapat dilihat dari jumlah setek yang mati, dimana varietas 1 memiliki jumlah setek yang mati lebih banyak dibandingkan varietas lainnya. Perbedaan pertumbuhan ini diduga karena adanya pengaruh dari varietas. Varietas yang berbeda umumnya memiliki kemampuan fisiologis, cara metabolisme, kandungan nutrisi dan hormon yang berbeda pula, sehingga menunjukkan pertumbuhan yang berbeda.

Perlakuan setek yang terendah yaitu setek tanpa daun (Tabel 7). Hal ini diduga karena pengaruh cadangan makanan dan hormon yang terdapat dalam bahan setek. Setek tanpa daun ini umumnya memiliki cadangan nutrisi yang sedikit, sehingga untuk pertumbuhan akar dan tunas cadangan makanan yang terdapat dibatang semakin menipis. Hal ini akan membuat setek membutuhkan waktu yang lama untuk pertumbuhan akar, dimana akar sangat berpengaruh untuk pembentukan tunas. Mustafa (2013), menyebutkan bahwa ada 2 faktor pendukung dan penghambat pertumbuhan tanaman, yaitu: 1). Faktor eksternal yang terdiri dari: cahaya, suhu, air, oksigen, nutrisi, kelembaban, keadaan tanah atau media, dan keadaan biologis disekitar tanaman. 2). Faktor internal yang terdiri dari: ketahanan tanaman terhadap lingkungannya, laju fotosintesis, hormon dalam tanaman, genetik pada tanaman, dan kandungan klorofil tanaman.

\section{Analisis media tanam}

Tanah podsol merupakan tanah yang umumnya tempat tumbuh $\mathrm{H}$. coronaria di hutan kerangas. Karakteristik tanah ini umumnya berpasir putih kehitaman, bersifat aerasi dan drainase tinggi. Sifatnya yang mudah melepas dan menyerap air ini maka media tanam menggunakan pemulsaan. Sartika
(2015), menyebutkan bahwa pemulsaan berfungsi untuk mencegah penguapan yang berlebih dari tanah. Mulsa yang digunakan dalam penelitian ini yaitu menggunakan moss atau lumut daun. Moss ini diambil dari hutan kerangas yang merupakan habitat tumbuh Hoya. Berdasarkan survei pendahuluan di hutan kerangas Air Anyir, Bangka menunjukkan bahwa $H$. coronaria ada yang tumbuh diatas moss $H$. coronaria dapat diperbanyak melalui biji. Pemencaran biji $H$. coronaria di hutan kerangas dibantu oleh angin dan semut. Biji yang jatuh diatas moss dapat tumbuh lebih baik dan cepat dibandingkan di tanah podsol. Hal ini mengingat kondisi hutan kerangas yang memiliki intensitas cahaya tinggi dan mudah mengalami kebakaran. Survei pendahuluan di hutan kerangas pada September - oktober 2015 masuk musim kemarau, banyak beberapa titik lokasi mengalami kebakaran. Hal ini menunjukkan bahwa $H$. coronaria yang tumbuh diatas tanah podsol lebih banyak yang mati, sedangkan yang tumbuh diatas moss masih ada yang hidup. Hal ini mengingat karena moss memiliki kemampuan menyimpan air yang tinggi. Vegetasi di hutan kerangas ini juga umumnya sampai tingkat pancang, dimana tidak adanya vegetasi pohon sehingga kondisi hutan ini tidak memiliki kanopi yang besar untuk menjaga kondisi lingkungannya dari pancaran sinar matahari langsung.

Hasil didapatkan bahwa kandungan organik pada tanah podsol memang rendah yaitu $1.17 \%$, kandungan anorganiknya 98.83\%, kadar air 1.06 dengan $\mathrm{pH}$ tanah 4.02. Moss memiliki kandungan organik $5.12 \%$, kandungan anorganiknya $94.88 \%$, kadar air 20.10 dengan pH tanah 5.04 (Tabel 4). Tingginya kadar air dan organik pada moss membantu tanaman memperoleh hara lebih cepat, sehingga pertumbuhan tanaman berlangsung lebih cepat pula. Hal ini sesuai dengan pernyataan Warino (2015), yang menyebutkan bahwa tanah podsol merupakan tanah yang memiliki unsur hara yang sangat rendah (nitrogen rendah), sifat aerasi dan draenase yang tinggi serta memiliki $\mathrm{pH}$ tanah masam antara 3,5-5,5. Anwar (2015), juga menyebutkan bahwa moss memiliki sifat mengikat air yang baik serta memiliki sistem drainase dan aerasi yang baik. Prameswari et al. (2014), mengatakan bahwa Moss mengandung unsur hara nitrogen yang tinggi dan sedikit fosfor dimana unsur hara nitrogen berfungsi untuk meningkatkan pertumbuhan vegetatif, mempercepat pembungaan dan mempengaruhi pembentukan batang. Wiryanta (2007), juga mengatakan bahwa moss mengandung nitrogen 2-3\% dan sangat baik untuk perkembangan akar. Edmonn et al. (1983 dalam Hayati et al. 2012), menyatakan bahwa ketersediaan nitrogen sangat menentukan dalam proses pertumbuhan tunas dan akar pada setek.

\section{Kondisi faktor lingkungan}

Faktor lingkungan merupakan salah satu pengaruh penting dalam pertumbuhan setek. Faktor lingkungan yang umumnya sangat berpengaruh 
dalam pertumbuhan tanaman yaitu intensitas cahaya, suhu dan kelembaban udara. Suhu yang tinggi dan kelembaban rendah merupakan ancaman bagi tanaman, sehingga tanaman akan lebih banyak transpirasi dan mengalami gejala kekeringan akibat kekurangan air. Berdasarkan penelitian menunjukkan bahwa kondisi faktor lingkungan di sekitar tanaman setek sesuai dengan kondisi lingkungan setek tanaman pada umumnya. Hasil didapatkan bahwa intensitas cahaya pagi 3762,5 dan sore hari 2888,6 lux , suhu udara pagi 28,52 dan sore hari $28,53 \mathrm{oC}$, dan kelembaban udara pagi 82,67 dan sore hari 82,42 $\%$ (Tabel 5). Hal ini sesuai dengan kondisi lingkungan pertumbuhan setek. Zainal et al. (1994) dalam Bayu (2013), menyebutkan bahwa iklim mikro yang optimal untuk pertumbuhan perakaran dan pertumbuhan setek yaitu kelembaban udara lebih dari $80 \%$, suhu udara lebih kurang 28 oC, dan intensitas cahaya lebih kurang 75\%. Hal ini juga didukung oleh pernyataan Kester (1983 dalam Budianto, Ahmad \& Suhartono, 2013), yang menyebutkan bahwa suhu perakaran optimal setek umumnya pada pagi hari yaitu $21^{\circ} \mathrm{C}$, pada siang hari $27^{\circ} \mathrm{C}$.

Kondisi lingkungan pada penelitian cukup baik sehingga mendukung pertumbuhan akar dan tunas. Hal ini karena cuaca pada saat penelitian memasuki musim penghujan, sehingga faktor lingkungan tersebut mendukung untuk keberhasilan tanaman setek. Tanaman uji tersebut diletakkan dibawah naungan, hal ini untuk menghindari kontak dengan sinar matahari langsung yang diduga akan terjadi penguapan yang besar oleh daun. Selain itu untuk mencegah busuknya pangkal batang akibat serapan air yang berlebihan dari luar karena hujan terus menerus. Hal ini didukung oleh pernyataan Willian dan Nelson (1992 dalam Budiarto \& Marwoto, 2007), yang menyebutkan bahwa tanaman yang diletakkan dibawah naungan berfungsi untuk menghindari dari cekaman lingkungan, selain itu untuk memperoleh kualitas tanaman setek yang baik sesuai yang di inginkan. Cekaman lingkungan yang terjadi seperti intensitas cahaya dan curah hujan yang berlebih di alam terbuka dapat menghambat proses metabolisme tanaman, sehingga tingkat keberhasilan setek dan kualitas setek yang dihasilkan juga rendah. Kramer dan Kozlowzky (1960 dalam Putrayandi, 2006), juga menyebutkan bahwa pengaruh eksternal yang terjadi di sekitar tanaman setek akan mempengaruhi fisiolgis tanaman, sehingga akan menyebabkan perbedaan pertumbuhan tanaman. Kartika et al. (2002 dalam Bayu 2013) menyebutkan bahwa keadaan fisiologis tanaman yang berbeda dalam suatu varietas akan menyebabkan perbedaan pertumbuhan tanaman.

Kondisi lingkungan di hutan kerangas yang merupakan habitat tumbuh H.coronaria berbeda dengan kondisi lingkungan di tempat penelitian. Umumnya kondisi lingkungan di habitat asli memiliki suhu tinggi, kelembaban rendah dan intensitas cahaya matahari tinggi. Herzegovina (2015), menyebutkan bahwa hutan kerangas memiliki rata-rata suhu 28,5-300C, kelembaban 66-73\% dan intensitas cahaya 18,89 X 103 lux. Perbedaan kondisi lingkungan di habitat asli dengan tempat penelitian menyebabkan adanya perbedaan karakter pertumbuhan tanaman. Berdasarkan survei pendahuluan dihutan kerangas menunjukkan bahwa karakter batang yang dimiliki beberapa diantaranya memiliki bulu, sedangkan di tempat penelitian tidak. Hal ini diduga untuk mencegah penguapan yang berlebih dari daun dan tanah. Daun yang dimiliki beberapa diantaranya berukuran kecil dibandingkan dengan tempat penelitian. Warna bunga yang dimiliki di lapangan umumnya juga lebih mencolok dibandingkan dengan di tempat penelitian. Hal ini karena pengaruh faktor lingkungan, dimana pembungaan dipengaruhi oleh cahaya matahari.

\section{KESIMPULAN DAN SARAN}

\section{Kesimpulan}

Berdasarkan hasil penelitian yang telah dilakukan dapat disimpulkan bahwa:

1. Perlakuan varietas dan setek menyebabkan adanya perbedaan pertumbuhan tanaman. Semua varietas dapat tumbuh pada perlakuan setek berdaun, baik yang berdaun 4 dan berdaun 2. Empat varietas dapat tumbuh pada perlakuan setek tanpa daun kecuali varietas 1 yang tidak dapat tumbuh jika tanpa daun.

2. Varietas yang menunjukkan pertumbuhan paling baik dan cepat tumbuh yaitu varietas 5. Setek yang menunjukkan pertumbuhan paling baik dan cepat tumbuh yaitu setek berdaun 4. Interaksi perlakuan antara varietas dan setek yang menunjukkan pertumbuhan terbaik dan cepat tumbuh yaitu perlakuan varietas 4 dengan setek berdaun 4 .

\section{Saran}

Perlu dilakukan penelitian mengenai pertumbuhan setek terhadap varietas yang lainnya. Selain itu penelitian mengenai faktor umur setek, panjang antar ruas dan perlakuan lainnya yang diduga mempengaruhi pertumbuhan tanaman juga perlu dilakukan.

\section{DAFTAR PUSTAKA}

Anwar T. 2015. Budidaya Tanaman Pembibitan Perawatan. http:// www. Best budidaya tanaman.com/2015/01/macam-macam- mediatanam-organik-dan-anorganik.html. diakses [23 Maret 2016]

Bayu H.H. 2013. Pengaruh Panjang Setek dan Pemberian Rootone-F terhadap Pertumbuhan Setek Tanaman Buah Naga Merah (Hylocereus costaricenes). [Skripsi]. Bangka: Universitas Bangka Belitung

Budianto M, Ahmad A, Suhartono. 2013. Pertumbuhan Stek Cabe Jamu (Piper 
Retrofractum. Vahl) Pada Berbagai Campuran Media Tanam Dan Konsentrasi Zat Pengatur Tumbuh Rootone-F. Jurnal Penelitian Agroviror. 6(2):112-121.

Budiarto K, dan Marwoto B. 2007. Produktivitas Tanaman Induk Dan Kualitas Stek Varietas Krisan Di Rumah Plastik Dan Lahan Terbuka. Jurnal J. Hort. 17(4):321-327.

Dewi I.R. 2008. Peranan dan Fungsi Fitohormon bagi Pertumbuhan Tanaman. Makalah Penelitian. Bandung: Universitas Padjajaran

Diaguna R. 2014. Panduan Praktikum Dasar- dasar Ilmu Tanah. Bangka: Jurusan Agroteknologi, Fakultas Pertanian, Perikanan dan Biologi, Universitas Bangka Belitung

Hardjadinata S. 2010. Budi Daya Buah Naga Super Red Secara Organik. Depok: Penebar Swadaya

Harjanto H, dan Nisa R. 2007. Memperbanyak Tanaman Hias Favorit. Jakarta: Penebar Swadaya

Hayati E., Sabaruddin dan Rahmawati. 2012. Pengaruh Jumlah Mata Tunas dan Komposisi Media Tanam terhadap Pertumbuhan Setek Tanaman Jarak Pagar (Jatropha curcus L.). Agrista. 16(3):1-16.

Herzegovina E.S. 2015. Karakterisasi Habitat Hoya coronaria Blume di Kawasan Hutan Kerangas Air Anyir Kabupaten Bangka. [Skripsi]. Bangka: Universitas Bangka Belitung

Kaisar I. 2014. Perumbuhan Eksplan Bawang Putih (Allium sativum L.) pada Beberapa Konsentrasi Sukrosa dan Arang Aktif. [Skripsi]. Bengkulu: Universitas Bengkulu

Kissinger, Ervizal A.M.Z., Latifah K.D., dan Iskandar Z.S. 2013. Keanekaragaman Jenis Tanaman Obat dari Hutan Kerangas. Jurnal Penelitian Hutan Tropis. 1(1):17-23.

Kurnia U, Agus F , Adimihardja A, Dariah A. 2006. Sifat Fisik Tanah dan Metode Analisisnya. Departemen Pertanian:Agro Inovasif

Mardiati T. 2007. Respon Morfofisiologis Beberapa Varietas Kacang Tanah (Arachis hypogaea L.) Terhadap Cekaman Kekeringan. [Skripsi]. Sumatera: Universitas Sumatera Utara

Mustafa R. 2013. Pertumbuhan dan Perkembangan Tanaman. http://www. Rieyahniedam. blogspot.
com/2013/05/Pertumbuhan-dan-Perkembangan Tanaman.html [23 Maret 2016]

Nalurita N. 2004. Pengaruh Media Semai terhadap Perkecambahan Strophanthus gratus (Wallich \& Hook) Baillos. Jakarta: UIN Syarif Hidayatullah

Pasetriyani. 2013. Pengaruh Macam Media Tanam dan Zat Pengatur Tumbuh Growtone terhadap Pertumbuhan Stek Batang Tanaman Jarak Pagar (Jatropa curcas Linn). Jurnal Pertanian. 4(1): 34-57.

Prameswari Z.K., Trisnawati, S dan Waluyo, S. 2014. Pengaruh Macam Media dan Zat pengatur Tumbuh terhadap Keberhasilan Cangkok Sawo (Manilkara zapota (L.) Van Royen) pada Musim Penghujan. Vegetalika. 3(4):107-118.

Putrayandi P. 2006. Respon Pertumbuhan Vegetatif Tanaman Anggrek Dendrobium (Dendrobium sp.) terhadap Penggunaan Media Tanam dan Dosis Pupuk NPK. [Skripsi]. Bangka: Universitas Bangka Belitung

Rahayu S. 2010. Sebaran dan Keragaman Genetik Populasi Hoya multiflora Blume (Asclepiadaceae) di Taman Nasional Gunung Gede Pangrao dan Sukamantri Taman Nasional Gunung Halimun Salak. [Tesis]. Bogor : IPB

Rahayu S. 2012a. Potensi dan Konservasi Jenis- Jenis Hoya Dataran Tinggi Pulau Jawa. Berk.Penel. Hayati. 18(1):1-7

Sandra. 2008. Pertumbuhan Bibit Soft Cutting Jarak Pagar pada Panjang Setek yang Berbeda dengan Pemberian IBA dan NAA. [Skripsi]. Bangka: Universitas Bangka Belitung

Sartika T.V. 2015. Pemulsaan. http://www. Tanti Virga Sartika.blogspot.com/2015/11/pemulsaanterhadap-media-tanam.html. diakses [11 Desember 2015]

Sitompul S.M dan Guritno. 1995. Analisis Pertumbuhan Tanaman. Yogyakarta: UGM

Warino J. 2015. Pengertian Unsur Hara dan Pengaruhnya terhadap Tanaman. http:// jokowarino.id/ Pengertian- Unsur- Hara- danPengaruhnya- Terhadap-Tanaman. html. diakses [18 Oktober 2015]

Wiryanta BTW. 2007. Media Tanam untuk Tanaman Hias. Jakarta Selatan: Agromedia pustaka 